\title{
Nonviral transfection of human umbilical cord blood dendritic cells is feasible, but the yield of dendritic cells with transgene expression limits the application of this method in cancer immunotherapy
}

\author{
Sergiusz Markowicz ${ }^{1 凶}$, Joanna Niedzielska ${ }^{1}$, Marcin Kruszewski ${ }^{1,2}$, Tomasz Ołdak ${ }^{1,3}$, \\ Agnieszka Gajkowska1, Eugeniusz K. Machaj ${ }^{1,3}$, Henryk Skurzak ${ }^{1}$ and \\ Zygmunt Pojda ${ }^{1,3}$
}

${ }^{1}$ The Maria Skłodowska-Curie Memorial Cancer Center and Institute of Oncology, Warszawa, Poland; ${ }^{2}$ Institute of Nuclear Chemistry and Technology, Warszawa, Poland, ${ }^{3}$ WIHE Institute of Hygiene and Epidemiology, Warszawa, Poland; ${ }_{e}$-mail: sergiusz@coi.waw.pl

Received: 12 May, 2005; revised: 05 October, 2005; acccepted: 16 December, 2005 available on-line: 09 January, 2006

\begin{abstract}
Dendritic cells (DC) generated from human umbilical cord blood might replace patients' DC in attempts to elicit tumor-specific immune response in cancer patients. We studied the efficiency of transfection of human cord blood DC with plasmid DNA carrying the enhanced version of green fluorescent protein (EGFP) as a reporter gene, to test if nonviral gene transfer would be a method to load DC with protein antigens for immunotherapy purposes. Cord blood mononuclear cells were cultured in serum-free medium in the presence of granulocyte-monocyte colony stimulating factor (GM-CSF), stem cell factor (SCF) and Flt-3 ligand (FL), to generate DC from their precursors, and thereafter transfected by electroporation. Maturation of DC was induced by stimulation with GM-CSF, SCF, FL and phorbol myristate acetate (PMA). Transfected DC strongly expressed EGFP, but transfection efficiency of DC, defined as $\mathrm{HLA}^{-D R^{+}}$cells lacking lineage-specific markers, did not exceed $2.5 \%$. Expression of the reporter gene was also demonstrated in the DC generated from transfected, purified $\mathrm{CD} 34^{+}$cord blood cells, by stimulation with GM-CSF, SCF, FL, and tumor necrosis factor $\alpha$ (TNF- $\alpha$ ). Transfection of $\mathrm{CD} 34^{+}$cells was very efficient, but proliferation of the transfected cells was much reduced as compared to the untransfected cells. Therefore, the yield of transgene-expressing DC was relatively low. In conclusion, nonviral transfection of cord blood DC proved feasible, but considering the requirements for immunotherapy in cancer patients, transfection of differentiated DC or generation of DC from transfected hematopoietic stem cells provide only a limited number of DC expressing the transgene.
\end{abstract}

Keywords: gene transfer, dendritic cells, umbilical cord blood, CD $34^{+}$cells, green fluorescent protein, electroporation

Bone marrow-derived DC are the only antigen-presenting cells able to induce the response of naive T cells (Banchereau \& Steinman, 1998). Cancer therapy based on the use of DC to present tumorassociated antigens has been shown to elicit tumorspecific immune response in humans, and resulted in clinical responses in a substantial proportion of patients (for a review, see Fong \& Engleman, 2000; Schuler et al., 2003). So far, several strategies of load- ing DC with tumor antigens ex vivo have been used in clinical trials. DC were pulsed with tumor proteins (Hsu et al., 1996; Timmerman et al., 2002), tumor peptides or whole lysates of tumor cells (Nestle et al., 1998), or fused with tumor cells (Krause et al., 2002). However, the procedures of vaccination using DC pulsed with tumor lysates or DC-tumor cell hybridomas depend on the accessibility of autologous tumor cells, and the use of peptides for vaccination

Abbreviations: CBMNC, cord blood mononuclear cells; DC, dendritic cells; EGFP, enhanced green fluorescent protein; FL, Flt-3 ligand; GM-CSF, granulocyte macrophage-colony stimulating factor; HSA, human serum albumin; lin, lineage; MHC, major histocompatibility complex; moAb, monoclonal antibody; PerCP, peridinin chlorophyll protein; PE, phycoerythrin; PMA, phorbol myristate acetate; SCF, stem cell factor; TNF- $\alpha$, tumor necrosis factor $\alpha$; TPO, thrombopoietin. 
is limited by the major histocompatibility complex (MHC) restrictions and by the limited number of known tumor peptides. Therefore, regarding all the limitations, transfection of DC with DNA encoding tumor-associated proteins may become an alternative method to obtain DC that endogenously express and process tumor proteins, and present multiple tumor epitopes to $\mathrm{CD} 8^{+} \mathrm{T}$ lymphocytes in the context of MHC class I molecules.

The choice and accessibility of DC is another important issue in immunotherapy. Deficites of DC count and their defective function in cancer patients (Gabrilovich et al., 1997; Savary et al., 1998) may limit the accessibility of patients' DC for vaccination, and consequently may hamper attempts to design vaccines based on autologous DC. This problem could be potentially overcome by the use of allogeneic DC matching the patient's MHC class I haplotype. Human umbilical cord blood can be considered as a potential source of allogeneic DC for vaccination against cancer. Cord blood mononuclear cells (CBMNC) contain a relatively high percentage of both hematopoietic stem cells and committed DC precursors which, when stimulated with GM-CSF and TNF- $\alpha$, proliferate and differentiate into functionally mature DC (Caux et al., 1992; Santiago-Schwarz et al., 1992). SCF and FL co-stimulate the generation of DC from hematopoietic progenitors induced by GM-CSF and TNF- $\alpha$ (Siena et al., 1995). Differentiation of CD34 ${ }^{+}$ hematopoietic progenitors into mature functional DC is also induced by stimulation with phorbol ester - PMA (Davis et al., 1998). Cord blood DC generated in vitro are able to process soluble antigens and prime naive T cells (Caux et al., 1995; Davis et al., 1998).

This is the first study comparing two strategies of production of transfected DC: direct electroporation of differentiated DC derived from umbilical cord blood CD34 ${ }^{+}$cells, and electroporation of human umbilical cord blood hematopoetic CD $34^{+}$cells followed by their differentiation to mature DC. In the former procedure the number of transfected DC was limited because of the low efficiency of electroporation. In the latter procedure, in spite of the high efficiency of electroporation, the number of transgene-expressing mature DC was limited because the proliferation rate of transfected $\mathrm{CD}_{3} 4^{+}$cell population was lower as compared to the untransfected cells.

\section{MATERIALS AND METHODS}

Cell isolation. Cord blood samples were collected from full-term normal deliveries. CBMNC were isolated by density gradient centrifugation on Ficoll-Uropoline (density $1.077 \mathrm{~g} / \mathrm{ml}$ ). The CD34 ${ }^{+}$cell fraction was isolated using CD34 Direct Isolation Kit (Miltenyi Biotec), according to the manufacturer's recommendations, as previously described (Ołdak et al., 2002).

Induction of DC growth and maturation in CBMNC cultures. CBMNC were cultured in teflon vessels in AIM V Medium containing 0.25\% human serum albumin (HSA) (Life Technologies), supplemented with GM-CSF ( $800 \mathrm{U} / \mathrm{ml}$; R\&D Systems), SCF (20 ng/ml; R\&D Systems) and FL (20 ng/ml; R\&D Systems), for 3, 5 or 11 days before electroporation. After electroporation, cells were cultured in AIM V Medium supplemented with GM-CSF, SCF, FL and PMA (50 ng/ml; Sigma).

Generation of DC in cultures of isolated $\mathrm{CD}^{+} 4^{+}$cells. Isolated $\mathrm{CD} 34^{+}$cells were cultured at a cell density of $1 \times 10^{5} / \mathrm{ml}$ for 2 days before electroporation in CellGro Stem Cell Growing Medium (SCGM) (CellGenix) for serum-free culture of hematopoietic stem and progenitor cells, supplemented with SCF (20 ng/ml), trombopoietin (TPO) (50 ng/ $\mathrm{ml}$; PeproTech EC) and FL $(50 \mathrm{ng} / \mathrm{ml})$, as previously described (Ołdak et al., 2002). After electroporation, CD $34^{+}$cells were cultured in CellGro SCGM supplemented with GM-CSF $(800 \mathrm{U} / \mathrm{ml})$, SCF $(25 \mathrm{ng} / \mathrm{ml})$ and FL (50 ng/ml). TNF- $\alpha$ ( $50 \mathrm{U} / \mathrm{ml} ; \mathrm{R} \& \mathrm{D}$ Systems) was added to the culture medium one day after electroporation.

Electroporation. Electroporation was performed in $0.4 \mathrm{~cm}$ gap sterile disposable cuvettes using a Gene Pulser (BioRad) or a BTX ECL600 instrument (Gentronix). CBMNC $\left(2-4 \times 10^{6}\right)$ were suspended in $250 \mu \mathrm{l}$ AIM V Medium. Plasmid DNA (pEGFP-N; Clontech), carrying EGFP as a reporter gene under the control of the CMV promoter, was added to the cell suspension at concentrations of $40 \mu \mathrm{g} / \mathrm{ml}$ or $80 \mu \mathrm{g} / \mathrm{ml}$ chosen after preliminary testing of concentrations ranging from 8 to $80 \mu \mathrm{g} / \mathrm{ml}$. Cells electroporated without the plasmid served as a control. For the CBMNC population, various combinations of the following electropulse parameters were applied: voltage: $250 \mathrm{~V}$ or $300 \mathrm{~V}$; capacitance: $500 \mu \mathrm{F}, 950 \mu \mathrm{F}$ or $1600 \mu \mathrm{F}$; resistance: $48 \Omega, 186 \Omega$, $720 \Omega$ or $\infty \Omega$. Pulse length fell within the range of 31 to $63 \mathrm{~ms}$.

Isolated $\mathrm{CD}^{+} 4^{+}$cells were electroporated at the parameters set previously as optimal (Ołdak et al., 2002). CD34 $4^{+}$cells $\left(2-7 \times 10^{5}\right)$ were suspended in $500 \mu \mathrm{l}$ of CellGro medium supplemented with $1 \%$ HSA. Plasmid DNA was added at a concentration of $20 \mu \mathrm{g} / \mathrm{ml}$. Voltage was set at $220 \mathrm{~V}$, resistance at 246 $\Omega$ and capacitance at $1600 \mu \mathrm{F}$.

Flow cytometric analysis. Transfection efficiency, cell viability and immunophenotype were determined by flow cytometry. Phycoerythrin (PE)conjugated anti-CD3, -CD11b, -CD14, -CD16, -CD20, -CD34, -CD80, -CD86 or -CD83 monoclonal antibod- 
ies (moAbs), peridinin chlorophyll protein (PerCP)conjugated anti-HLA-DR moAb, and PE-conjugated mouse $I g G_{1}$ and $I_{g} G_{2 a}$ controls were purchased from Becton-Dickinson. Cell samples were examined in a FACSCalibur flow cytometer (Becton-Dickinson). To identify DC and their precursors in the CBMNC population and among the cells generated from purified cord blood hematopoietic cells, cell samples were stained with a mixture of PE-conjugated moAbs recognizing CD3, CD11b, CD14, CD16, and CD20 lineage-associated molecules (lin cocktail) and HLA-DR-PerCP moAb. In a selected experiment, anti-CD34 moAb was included in the lin mixture of moAbs, to exclude $\mathrm{CD} 34^{+}$progenitors from the linnegative population in cytometric evaluation. Thirty or twenty, thousand events that fell within the gate encompassing nucleated cells were collected from immunolabelled samples of CBMNC cultured for $1,2,3$ or 4 days post-electroporation, and of cells generated from purified $\mathrm{CD} 34^{+}$hematopoietic stem cells after 2, 5, 8, 12 or 15 days of culture post-electroporation. The absolute numbers of DC and their precursors (cells of the lin-HLA-DR ${ }^{+}$phenotype), hematopoietic $\mathrm{CD} 34^{+}$cells, and cells expressing the co-stimulatory molecule CD86 or the activation molecule CD83, were backcalculated from their proportion in CBMNC, as determined by flow cytometric analysis, and the total number of CBMNC in the culture. Cell viability of CBMNC was determined by staining with propidium iodide (PI, $0.3 \mu \mathrm{g} / \mathrm{ml}$ ) for $30 \mathrm{~min}$ before flow cytometric acquisition.

\section{RESULTS}

\section{Transfection of DC generated in CBMNC cultures}

Total CBMNC population pre-cultured for 3, 5 or 11 days in the presence of GM-CSF, SCF, and FL to promote DC growth, was transfected at various electrical parameters to optimize the conditions of electroporation. After electroporation the cells were cultured in the presence of GM-CSF, SCF, FL, and PMA added to the culture to induce DC differentiation. Our preliminary experiments had shown that there was a more pronounced decrease of cell viability after electroporation at the voltage set at 300 $\mathrm{V}$ than at $250 \mathrm{~V}$ (not shown). Therefore, further experiments were performed at $250 \mathrm{~V}$. Two days after electroporation the viability of CBMNC pre-cultured for 3 days before electroporation ranged from $49.3 \%$ to $88.7 \%$ (median value $79.0 \%, \mathrm{n}=7$ ). The viability of CBMNC pre-cultured for 5 or 11 days before transfection fell within the same range. EGFP expression was found mostly in viable cells (not shown). When the capacitance was set at $950 \mu \mathrm{F}$, the percentage of viable CBMNC expressing the reporter gene on days 1 and 2 after electroporation ranged from $0.19 \%$ to $2.11 \%(n=6)$ and from $0.17 \%$ to $1.61 \%$, respectively. When the capacitance was set at $1600 \mu \mathrm{F}$, the percentage of $\mathrm{EGFP}^{+}$cells among viable CBMNC on days 1 and 2 after electroporation ranged from $1.80 \%$ to $2.64 \%(n=3)$, and from $2.08 \%$ to $2.32 \%$, respective-

Table 1. Transfection efficiency of total cord blood mononuclear cells (CBMNC), DC and their precursors identified as lin-HLA-DR ${ }^{+}$cells, and $\mathrm{CD}^{-} 4^{+}$cell subsets analysed by flow cytometry 2 days after electroporation

\begin{tabular}{|c|c|c|c|c|c|c|c|c|c|c|c|}
\hline \multirow[t]{2}{*}{$\begin{array}{l}\text { Exp. } \\
\text { No. }\end{array}$} & \multirow{2}{*}{$\begin{array}{l}\text { Culture } \\
\text { before } \\
\text { trans- } \\
\text { fection } \\
\text { (days) }\end{array}$} & \multirow{2}{*}{$\begin{array}{l}\text { DNA } \\
\text { conc. } \\
(\mu \mathrm{g} / \mathrm{ml})\end{array}$} & \multirow{2}{*}{$\begin{array}{l}\text { Electropulse } \\
\text { parameters } \\
\text { (capacitance; } \\
\text { resistance; } \\
\text { voltage; pulse } \\
\text { time) }\end{array}$} & \multicolumn{4}{|c|}{$\begin{array}{l}\text { Transfection efficiency } \\
\text { (\% of } \mathrm{EGFP}^{+} \text {cells) }\end{array}$} & \multirow{2}{*}{$\begin{array}{l}\text { Viabi- } \\
\text { lity of } \\
\text { CBMNC } \\
(\%)\end{array}$} & \multirow{2}{*}{$\begin{array}{l}\operatorname{lin}^{-} \\
\text {HLA-DR }^{+} \\
\% \text { of CBM }\end{array}$} & \multirow[t]{2}{*}{$\begin{array}{l}\mathrm{CD}^{+} 4^{+} \\
\text {HLA-DR }^{+}\end{array}$} & \multirow[t]{2}{*}{$\begin{array}{l}\text { CD34 }^{+-} \\
\text {HLA-DR }^{-}\end{array}$} \\
\hline & & & & $\begin{array}{l}\text { CB- } \\
\text { MNC }\end{array}$ & $\begin{array}{l}\operatorname{lin}^{-} \\
\text {HLA- } \\
\text { DR }^{+}\end{array}$ & $\begin{array}{l}{\text { CD } 34^{+}}^{+} \\
\text {HLA- }^{-} \\
\text {DR }^{+}\end{array}$ & $\begin{array}{l}\mathrm{CD}^{+} 4^{+} \\
\mathrm{HLA}^{-} \\
\mathrm{DR}^{-}\end{array}$ & & & & \\
\hline 2. & 3 & 40 & $\begin{array}{l}950 \mu \mathrm{F} ; 720 \Omega \\
250 \mathrm{~V} ; 40.4 \mathrm{~ms}\end{array}$ & 2.29 & $1.43^{*}$ & 2.07 & 18.75 & 86.21 & $32.99^{*}$ & 2.02 & 0.44 \\
\hline 3. & 3 & 40 & $\begin{array}{l}1600 \mu \mathrm{F} ; 186 \Omega \\
250 \mathrm{~V} ; 61.5 \mathrm{~ms}\end{array}$ & 2.13 & $2.43^{* *}$ & 6.40 & 31.46 & 83.75 & $28.83^{* *}$ & 2.89 & 0.30 \\
\hline 5. & 3 & 40 & $\begin{array}{l}1600 \mu \mathrm{F} ; 48 \Omega \\
250 \mathrm{~V} ; 38.4 \mathrm{~ms}\end{array}$ & 1.74 & $1.86^{*}$ & 2.81 & 56.99 & 79.54 & $29.40^{*}$ & 1.16 & 0.31 \\
\hline 7. & 5 & 80 & $\begin{array}{l}950 \mu \mathrm{F} ; \infty \Omega \\
250 \mathrm{~V} ; 61.0 \mathrm{~ms}\end{array}$ & 1.17 & $0.95^{*}$ & nd & nd & 49.27 & $21.13^{*}$ & nd & nd \\
\hline 8. & 11 & 80 & $\begin{array}{l}950 \mu \mathrm{F} ; \infty \Omega \\
250 \mathrm{~V} ; 61.0 \mathrm{~ms}\end{array}$ & 0.70 & $1.90^{*}$ & nd & nd & 78.47 & $8.58^{*}$ & nd & nd \\
\hline
\end{tabular}

${ }^{a}$ Cell viability was determined by flow cytometry as \% of PI-negative cells; ${ }^{*}$ lin mixture consisted of anti-CD3, -CD11b, -CD14, -CD16, and -CD20 moAbs; **lin mixture consisted of anti-CD3, -CD11b, -CD14, -CD16, -CD20, and -CD34 moAbs; nd, not done. 
A

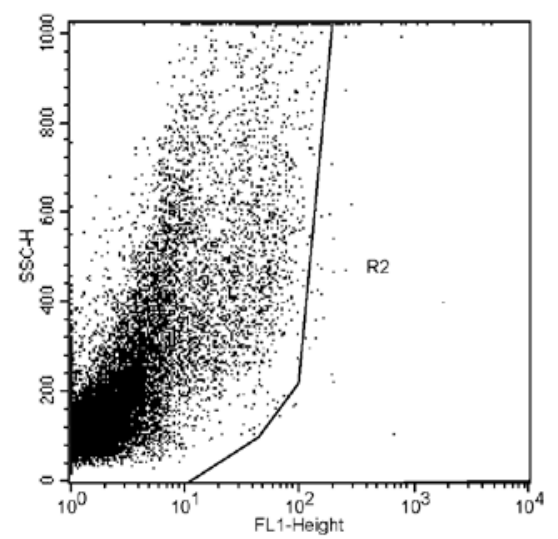

C

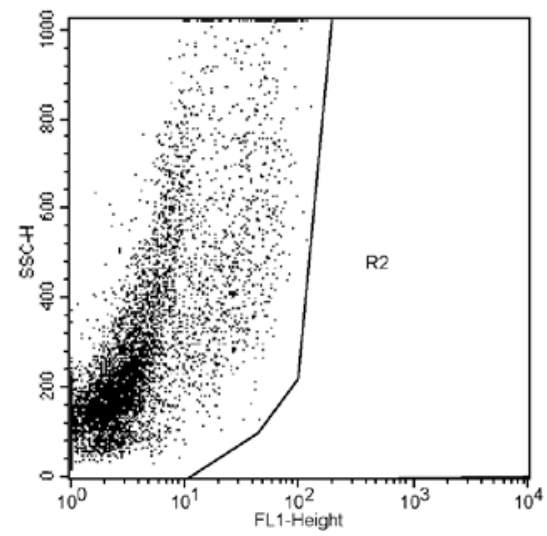

B

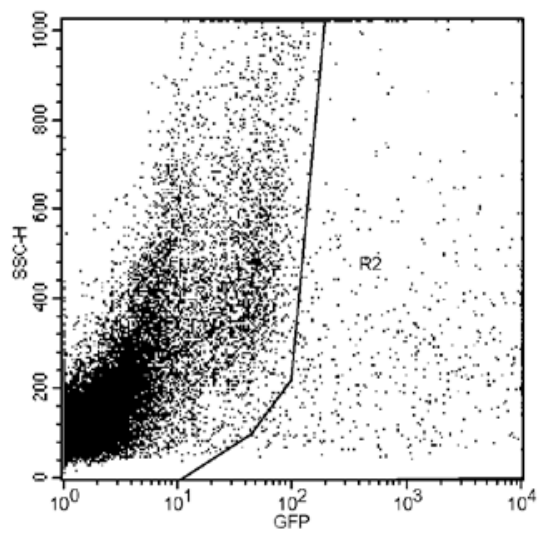

D

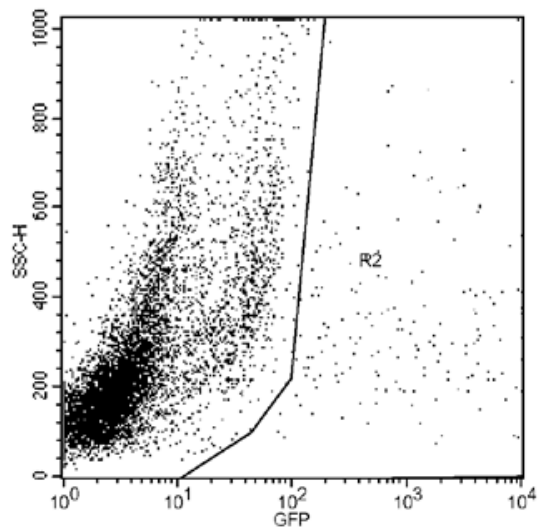

Figure 1. Flow cytometric analysis of transfection efficiency of total CBMNC and DC.

Evaluation of EGFP expression is shown for total CBMNC electroporated without (A) or with plasmid DNA (B), and for DC identified by flow cytometry among CBMNC electroporated without (C) or with plasmid DNA (D). DC were gated as lineage marker-negative HLA-DR ${ }^{+}$cells. In this experiment, the lineage cocktail included anti-CD34 moAb to exclude hematopoietic progenitors from the lin-negative population.

ly. The transfection efficiency after electroporation at the capacitance of $500 \mu \mathrm{F}$ did not exceed $0.56 \%$ of viable CBMNC $(\mathrm{n}=3)$.

The efficiency of transfection of DC generated in CBMNC cultures was determined by flow cytometry analysis of $\mathrm{EGFP}^{+}$cell content within the gate encompassing cells of the lin-HLA-DR ${ }^{+}$phenotype, as shown in Fig. 1. The efficiency of transfection of lin-HLA-DR ${ }^{+}$cells two days after electroporation did not exceed $2.5 \%$, and was similar to the efficiency found for total CBMNC (Table 1). Cells of the lin-HLA-DR ${ }^{+}$phenotype contained a similar proportion of $\mathrm{EGFP}^{+}$cells to that identified in the much less numerous CD34 $4^{+} \mathrm{HLA}-\mathrm{DR}^{+}$cell fraction. This means that $\mathrm{EGFP}^{+} \mathrm{CD} 34^{+}$progenitors were only a minor population among lin-HLA-DR ${ }^{+}$cells expressing EGFP two days after transfection, while the majority of trasfected lin-HLA-DR ${ }^{+}$cells became differentiated, CD34-negative cells (Table 1, Exp. No. 1 and 3 ). This observation was also verified by stain- ing cultured CBMNC population with the use of a mixture of moAbs recognizing lineage-specific markers, supplemented with anti-CD34 moAb, to exclude $\mathrm{CD} 34^{+}$progenitors from the gate encompassing lin $^{-}$ HLA-DR ${ }^{+}$cells (Table 1, Exp. No. 2). The efficiency of transfection of CBMNC fractions phenotyped as

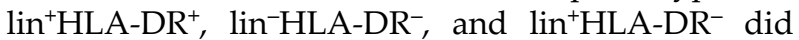
not exceed $2.65 \%$, and was not substantially higher than the efficiency of transfection of lin-HLA-DR ${ }^{+}$ cells (not shown). CD34 ${ }^{+} \mathrm{HLA}_{-} \mathrm{DR}^{-}$cells were the only ones highly susceptible to transfection among CBMNC cultured for 5 days (Table 1). Cells maintaining the progenitor phenotype comprised a minor fraction $(<0.5 \%)$ of CBMNC cultured for 5 days.

\section{Differentiation of DC expressing the reporter gene from transfected $\mathrm{CD} 34^{+}$progenitor cells}

As shown here and in our previous study (Ołdak et al., 2002), electrotransfection of DC and 

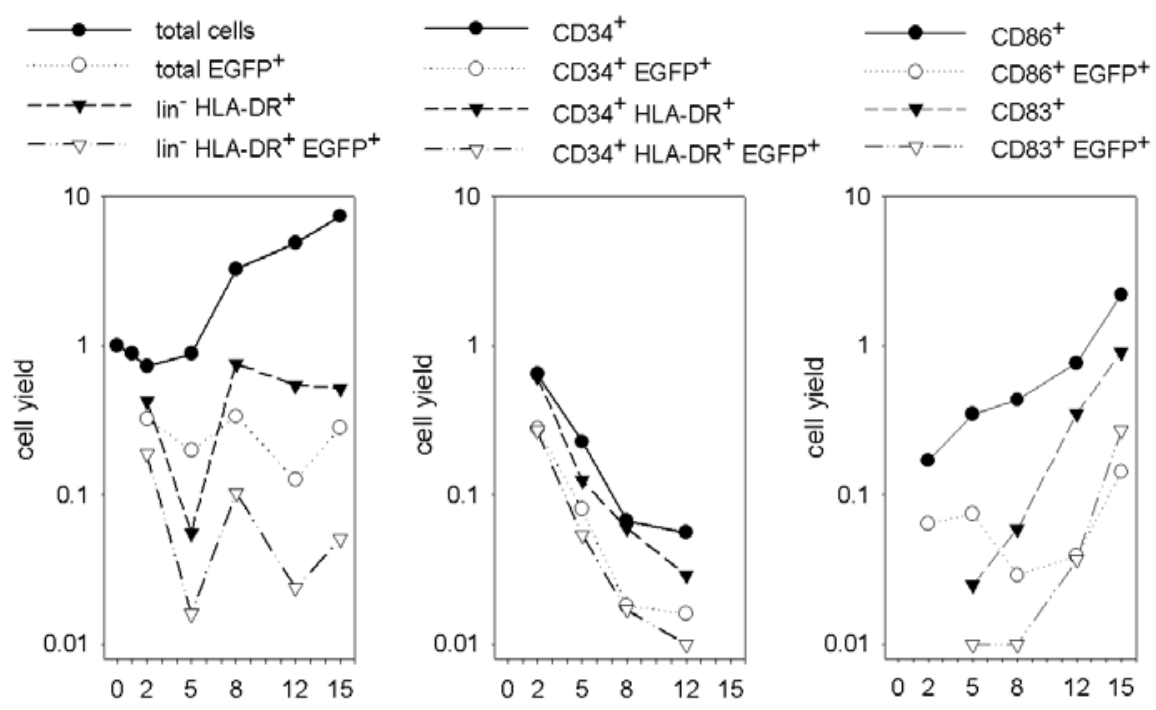

time post-electroporation [days]

time post-electroporation [days]

time post-electroporation [days]

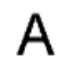

B

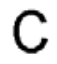

Figure 2. The yield of total cultured cells, of cell subpopulations identified by flow cytometry, and of EGFP-expressing cells in the culture originated from electrotransfected CD $34^{+}$hematopoietic cord blood cells.

The yield of total cultured cells and lin ${ }^{-}$HLA-DR ${ }^{+}$cells (A), CD $34^{+}$cells and CD $34^{+} \mathrm{HLA}^{-\mathrm{DR}}{ }^{+}$cells (B), CD86 ${ }^{+}$cells and $\mathrm{CD}^{2} 3^{+}$cells (C), and $\mathrm{EGFP}^{+}$cells within these populations at each time-point was related to the initial number of cells in the culture after electroporation with plasmid.

of other subsets generated from pre-stimulated CBMNC population resulted in a relatively low efficiency as compared to the efficiency of transfection of $\mathrm{CD}_{3} 4^{+}$hematopoietic cells. Therefore, we attempted to generate DC from transfected cord blood $\mathrm{CD} 34^{+}$cells. At first, purified CD34 ${ }^{+}$cells were cultured for 2 days in the presence of SCF, TPO, and $\mathrm{FL}$, what supported the growth of progenitor cells without a loss of their pluripotency. Thereafter, the prestimulated cells were electroporated at the optimal capacitance $(1600 \mu \mathrm{F})$ and voltage $(220 \mathrm{~V})$, and cultured in the presence of GM-CSF, SCF, FL, and TNF- $\alpha$ selectively promoting growth and differentiation of DC. Two days after electroporation, $89 \%$ of the cultured cells still expressed the CD34 marker of progenitor cells, and $44 \%$ of the cultured cells expressed the reporter gene. This means that at this time point the majority of cells of the lin ${ }^{-} \mathrm{HLA}-\mathrm{DR}^{+}$ phenotype belonged to the subpopulation of CD34positive progenitor cells. During five days following electroporation, the proportion of differentiated cells expressing lineage markers increased, whereas the proportion of $\operatorname{lin}^{-} \mathrm{HLA}-\mathrm{DR}^{+}$and of CD34 ${ }^{+} \mathrm{HLA}-\mathrm{DR}^{+}$ cells decreased (Fig. 2A, B). During the next three days, an increase of the absolute number of differentiated DC of the lin ${ }^{-}$HLA-DR ${ }^{+}$phenotype, lacking the CD34 marker, was accompanied by a further decrease of the CD34 ${ }^{+} \mathrm{HLA}-\mathrm{DR}^{+}$cell subpopulation, due to differentiation of $\mathrm{CD} 34^{+}$progenitors in the culture. Eight days post-electroporation, the number of differentiated lin-HLA-DR ${ }^{+}$DC expressing EGFP exceeded the number of $\mathrm{CD}^{+} 4^{+}$cells expressing
EGFP. Fifteen days after electroporation, the majority of EGFP-expressing cells displayed the activation molecule CD83, known as a marker of mature DC, and the co-stimulatory molecule CD86, a marker of antigen-presenting cells (Fig. 2C). On day 15 postelectroporation, the numbers of $\mathrm{CD}^{+} 6^{+}$cells and of $\mathrm{CD}^{2} 3^{+}$cells exceeded the number of cells of the lin-HLA-DR ${ }^{+}$phenotype. Intermediate DC precursors transiently expressing the CD14 molecule might express the CD86 molecule, and a subset of DC expressing $\mathrm{CD} 11 \mathrm{~b}$ might express $\mathrm{CD} 83$. However, the compartment of cells identified as DC, according to the criterion of the lin ${ }^{-} \mathrm{HLA}-\mathrm{DR}^{+}$phenotype, included neither intermediate $\mathrm{CD} 14^{+} \mathrm{CD} 86^{+}$precursors of DC nor the $C D 11 b^{+} C D 83^{+}$DC subset, since the lin mixture used in this study contained anti-CD14 and anti-CD11b monoclonal antibodies.

Transfected $\mathrm{CD} 4^{+}$hematopoietic cells were able to differentiate into DC, and a 7-fold expansion of total cell population was observed during 15 days of culture following electroporation with the plasmid. However, that was not accompanied by a proportional expansion of cells expressing the reporter gene. The absolute number of EGFP-expressing cells during the culture did not increase substantially over the value found two days post-electroporation. In addition, the total cell yield in the culture of mock-electroporated cells was more than one order of magnitude higher than the total cell yield in the culture of plasmid-electroporated cells (Fig. 3). Similarly, the yield of differentiated DC in the culture of mock-electroporated cells was much higher as 


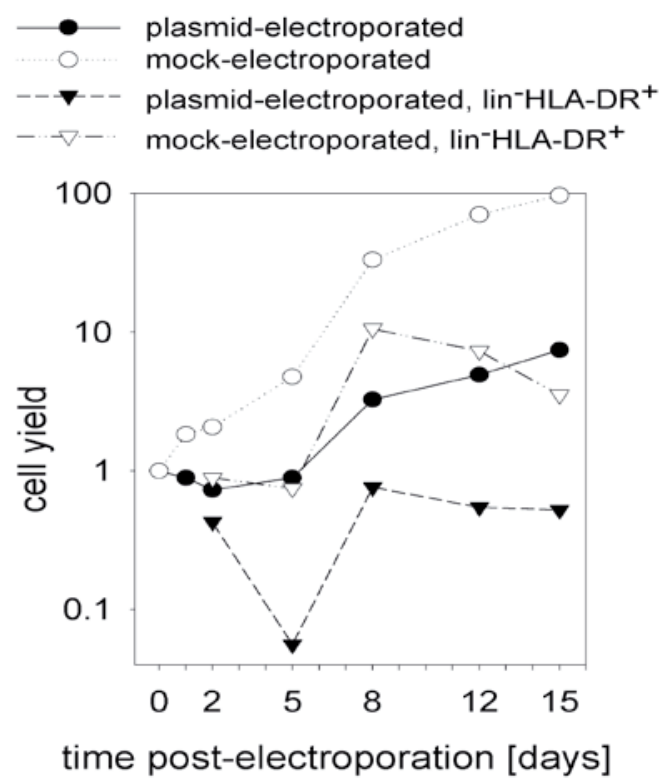

Figure 3. The yield of total and lin-HLA-DR ${ }^{+}$cells in cultures originated from mock-electroporated or plasmid-electroporated $\mathrm{CD}^{+} 4^{+}$hematopoietic cord blood cells related to the initial cell count in the culture after electroporation.

compared to the DC yield in the culture of plasmidelectroporated cells. This suggests that loading with plasmid DNA decreases the proliferation of $\mathrm{CD} 34^{+}$ hematopoietic cells and/or increases the rate of cell death of transfected cells in culture.

\section{DISCUSSION}

Dendritic cell-based vaccination appears to be a very promising strategy of inducing anti-cancer immune response. One of the crucial issues in attempts to engineer immune response with the use of DC is efficient loading of DC with antigens. Genetic manipulation of DC is considered a method of obtaining DC able to synthesize tumor associated antigens (TAA) de novo and to present multiple MHC class I-restricted epitopes of TAA. The use of DC that process endogeneous TAA may resolve the problem of preparing a set of synthetic tumor peptides for individual cancer patient. Viral transfection has proved so far to be an efficient method of engineering human DC expressing TAA. CD34 ${ }^{+}$ cell-derived DC as well as monocyte-derived DC were transduced with the use of viral vectors (Kim et al., 1997; Perez-Diez et al., 1998; Oki et al., 2001; Temme et al., 2002). However, the risk of oncogenesis or mutagenesis resulting from the insertion of a viral genome into the host DNA and the problem of immunogenicity of viral proteins remain a serious safety concern (Ying et al., 1999). This safety concern severely limits the use of engineered viruses in the clinical setting. Therefore, exploration of non-viral
DC transfection is of high interest in the field of immunotherapy.

In this study, we report the evaluation of two alternative strategies of obtaining cord blood DC expressing a transgene. One of these strategies was based on the electrotransfection of DC generated in the culture of CBMNC supplemented with cytokines promoting DC growth and differentiation from both pluripotent hematopoietic stem cells and committed myeloid DC precursors at various stages of differentiation. Although transfected DC brightly expressed EGFP, the transfection efficiency $(<2.5 \%)$ was much lower than the transfection efficiency of a minor fraction of hematopoietic cells of the $\mathrm{CD}_{3}{ }^{+} \mathrm{HLA}^{-\mathrm{DR}^{-}}$phenotype, persisting in CBMNC culture, and, similarly, much lower than the previously reported transfection efficiency of purified hematopoietic CD $34^{+}$cells, pre-stimulated for 2 days with a cytokine mixture inducing cell proliferation without a loss of their pluripotency ( $\mathrm{Wu}$ et al., 2001a; 2001b; Ołdak et al., 2002). The transfection efficiency of DC generated from CBMNC progenitors, described in our study, was of a similar magnitude as the transfection efficiency of monocyte-derived DC generated from peripheral blood monocytes, reported by others (Van Tendeloo et al., 1998; Strobel et al., 2000), but lower than the efficiency of gene transfer to DC derived from purified $\mathrm{CD} 34^{+}$hematopoietic progenitors $(12 \%)$ (Van Tendeloo et al., 1998). The proliferative potential of purified $\mathrm{CD}^{2} 4^{+}$hematopoietic progenitors is higher than that of committed myeloid DC precursors within CBMNC population, being at various stages of differentiation. This may suggest that the susceptibility to transfection of differentiating DC precursors is gradually reduced due to the gradual loss of their proliferative potential accompanying their differentiation in culture. It has been shown previously that the susceptibility to transfection with plasmid DNA depends on the proliferative potential of transfected cells. A mitogenic stimulus is required to make human peripheral blood $\mathrm{T}$ cells receptive for transfection (Van Tendeloo et al., 2000). Adult bone marrow $\mathrm{CD}_{4} 4^{+}$cells stimulated to proliferate become much more receptive to gene transfer with the use of plasmid DNA than unstimulated bone marrow CD34 ${ }^{+}$cells (Van Tendeloo et al., 2000). In addition, the ongoing process of differentiation of hematopoietic progenitor cells, in fact, may by itself affect the susceptibility of these cells to transfection, though the proportion of cells recruited to the cell cycle does not change. CD34 ${ }^{+}$cells isolated from mobilized peripheral blood of patients reach the maximal susceptibility to transfection within $24-48 \mathrm{~h}$ in culture, but later on the susceptibility decreases, although the percentage of cells in S-phase remains stable up to 4 days (Wu et al., 2001c). 
It has been shown previously that electrotransfection does not adversely affect the function of viable DC in antigen presentation. No significant impairment of the capacity of transfected DC to induce mixed lymphocyte reaction was found when DC maintained viability for a few days following electroporation (Van Tendeloo et al., 1998). In our study the majority of transfected CBMNC were viable 2 days after transfection. The viability was maintained later in the culture, but the percentage of EGFP-expressing cells was reduced by half 4 days after transfection (not shown). Regarding cancer immunotherapy purposes, the achieved transient gene expression by DC without a substantial loss of cell viability for a few days following electroporation might be sufficient for effective antigen presentation. However, the relatively low transfection efficiency would be the main obstacle in attempts to use DC transfected with plasmid DNA for immunotherapy purposes. Although the proportion of differentiated DC is relatively high among CBMNC stimulated with cytokines promoting DC growth and differentiation, multiple cord blood preparations would be required to perform a cycle of immunization of one cancer patient with the use of allogeneic cord blood DC transfected with a plasmid carrying tumor genes. Thus, further improvement of non-viral DNA transfection is desirable to make this method competitive with other methods of loading DC with antigens.

A new method of nucleoporation with the use of Amaxa Nucleofector, described by Lenz et al. (2003), made possible gene transfer to monocyte-derived DC with the use of plasmid DNA, with efficiencies approaching $60 \%$, but a loss of cell viability was observed within a few hours following transfection. Such a loss of DC viability after transfection is unacceptable regarding DC application for immunotherapy purposes, since it might substantially reduce the chance of reinjected DC getting in contact with T cells and presenting antigens in vivo. Therefore the use of the method described by Lenz et al. (2003) will be limited until the cell viability is improved.

Since the efficiency of DNA transfer to differentiating DC was low, we attempted to generate DC expressing a transgene from transfected CD34 ${ }^{+}$ cord blood hematopoietic cells by stimulation with a mixture of cytokines selectively promoting DC growth and differentiation. Hematopoietic CD $34^{+}$ cells were transfected with high efficiency. The transfected hematopoietic progenitors preferentially differentiated into cells of the DC phenotype. Following cell differentiation the majority of $\mathrm{EGFP}^{+}$ cells expressed CD83, a marker of mature DC. However, the yield of DC expressing the transgene after culture of plasmid-electroporated cells did not match the yield of expanded population of DC with undetectable EGFP expression. In addition, to- tal cell yield and DC yield in the culture of plasmid-electroporated cells did not match the total cell yield and DC yield, respectively, in the culture of mock-electroporated cells. Thus, generation of DC from transfected $\mathrm{CD} 34^{+}$cord blood hematopoietic would provide a very limited number of transgeneexpressing DC for cancer immunotherapy. Wu et al. (2001b) found previously that during stem cell differentiation transgene expression may differ in various cell populations, and may not be sustained in more differentiated cell populations. In their study, the yield of transgene-expressing cells generated from transfected CD $34^{+}$cord blood hematopoietic cells did not match the total cell yield after 11 days of culture in IL-3-, GM-CSF-, and G-CSFsupplemented medium. They found $\mathrm{EGFP}^{+}$cells among $\mathrm{CD}^{+} 3^{+} / \mathrm{CD}_{11} \mathrm{~b}^{+}$early myeloid cells, but no EGFP $^{+}$cells among more differentiated populations of $\mathrm{CD}^{+} 4^{+}$monocytes and $\mathrm{CD} 41 \mathrm{a}^{+}$megakaryocytes after the culture.

Comparative studies on gene delivery by mRNA electroporation and by plasmid DNA electroporation performed side-by-side have demonstrated that RNA electroporation results in a higher transfection efficiency of monocyte- or $\mathrm{CD}_{4} 4^{+}$cellderived DC and lower cytotoxicity (Strobel et al., 2000; Van Tendeloo et al., 2001; Sæbøe-Larssen et al., 2002; Lundqvist et al., 2002). RNA-transfected DC efficiently stimulate antigen-specific $\mathrm{T}$ cells, far better than DNA-transfected DC in side-by-side comparison (Strobel et al., 2000). Comparative studies on plasmid DNA transfection have also demonstrated that other methods may become an alternative for electroporation. For example, efficient tranfection by immunolipoplexes (Tan et al., 2005), cationic peptide (Irvine et al., 2000) or peptide/liposome systems (Uduehi et al., 2003) result in a higher transfection efficiency of monocyte- or $\mathrm{CD} 34^{+}$cell-derived DC, and a comparable toxicity. However, DC transfected with the use of immunolipoplexes render $\mathrm{T}$ cell anergic for further stimulation with antigens (Tan et al., 2005), and therefore the method seems suitable rather for tolerance induction protocols. The rapid decline of transgene expression after transfection by the peptide/liposome system (Uduehi et al., 2003) and the toxicity of the lipid compounds may limit the applicability of lipid-based methods in clinical settings. Further development of gene delivery methods is required to achieve progress in DC-based immunotherapy.

\section{Acknowledgements}

The authors thank Dr. Magdalena Chechlińska, Maria Sklodowska-Curie Memorial Cancer Center and Institute of Oncology, for reviewing the manuscript and for helpful discussion. 


\section{REFERENCES}

Banchereau J, Steinman RM (1998) Dendritic cells and the control of immunity. Nature 392: 245-252.

Caux C, Dezutter-Dambuyant C, Schmitt D, Banchereau J (1992) GM-CSF and TNF- $\alpha$ cooperate in the generation of dendritic Langerhans cells. Nature 360: 258-261.

Caux C, Massacrier C, Dezutter-Dambuyant C, Vanbervliet B, Jacquet C, Schmitt D, Banchereau J (1995) Human dendritic Langerhans cells generated in vitro from $\mathrm{CD} 34^{+}$progenitors can prime naive $\mathrm{CD} 4^{+} \mathrm{T}$ cells and process soluble antigen. J Immunol 155: 5427-5435.

Davis TA, Saini AA, Blair PJ, Levine PL, Craighead N, Harlan DM, June CH, Lee KP (1998) Phorbol esters induce differentiation of human $\mathrm{CD} 4^{+}$hemopoietic progenitors to dendritic cells: evidence for protein kinase C-mediated signaling. J Immunol 160: 3689-3697.

Hsu FJ, Benike C, Fagnoni F, Liles TM, Czerwinski D, Taidi B, Engleman EG, Levy R (1996) Vaccination of patients with B-cell lymphoma using autologous antigen-pulsed dendritic cells. Nat Med 2: 52-58.

Fong L, Engleman EG (2000) Dendritic cells in cancer immunotherapy. Annu Rev Immunol 18: 245-273.

Gabrilovich DI, Corak J, Ciernik IF, Kavanaugh D, Carbone DP (1997) Decreased antigen presentation by dendritic cells in patients with breast cancer. Clin Cancer Res 3: 483-490.

Irvine AS, Trinder PK, Laughton DL, Ketteringham H, McDermott RH, Reid SC, Haines AMR, Amir A, Husain R, Doshi R, Young LS, Mountain A (2000) Efficient nonviral transfection of dendritic cells and their use for in vivo immunization. Nat Biotechnol 18: 1273-1278.

Kim CJ, Prevette T, Cormier J, Overwijk W, Roden M, Restifo NP, Rosenberg SA, Marincola FM (1997) Dendritic cells infected with poxviruses encoding MART-1/Melan A sensitize $\mathrm{T}$ lymphocytes in vitro. J Immunother $\mathbf{2 0}$ 276-286.

Krause SW, Neumann C, Soruri A, Mayer S, Peters JH, Andreesen R (2002) The treatment of patients with disseminated malignant melanoma by vaccination with autologous cell hybrids of tumor cells and dendritic cells. J Immunother 25: 421-448.

Lenz P, Bacot SM, Frazier-Jessen MR, Feldman GM (2003) Nucleoporation of dendritic cells: efficient gene transfer by electroporation into human monocyte-derived dendritic cells. FEBS Lett 538: 149-154.

Lundqvist A, Noffz G, Pavlenko M, Sæbøe-Larssen S, Fong T, Maitland N, Pisa P (2002) Nonviral and viral gene transfer into different subsets of human dendritic cells yield comparable efficiency of transfection. J Immunother 25: 445-454.

Nestle FO, Alijagic S, Gilliet M, Sun Y, Grabbe S, Dummer R, Burg G, Schadendorf D (1998) Vaccination of melanoma patients with peptide- or tumor lysate-pulsed dendritic cells. Nat Med 4: 328-332.

Oki M, Ando K, Hagihara M, Miyatake H, Shimizu T, Miyoshi H, Nakamura Y, Matsuzawa H, Sato T, Ueda Y, Gansuvd B, Kato S, Hotta T (2001) Efficient lentiviral transduction of human cord blood $\mathrm{CD}^{+} 4^{+}$cells followed by their expansion and differentiation into dendritic cells. Exp Hematol 29: 1210-1217.

Ołdak T, Kruszewski M, Machaj EK, Gajkowska A, Pojda Z (2002) Optimisation of transfection of CD34+ hematopoietic cells derived from human umbilical cord blood. Acta Biochim Polon 49: 625-632.

Perez-Diez A, Butterfied LH, Li L, Chakraborty NG, Economou JS, Mukherji B (1998) Generation of CD8 ${ }^{+}$and $\mathrm{CD}^{+} \mathrm{T}$-cell response to dendritic cells genetically en- gineered to express the MART-1/Melan A gene. Cancer Res 63: 2127-2133.

Santiago-Schwarz F, Belilos E, Diamond B, Carsons SE (1992) TNF in combination with GM-CSF enhances the differentiation of neonatal cord blood stem cells into dendritic cells and macrophages. J Leukoc Biol 52: 274-281.

Savary AC, Grazziutti ML, Melichar B, Przepiorka D, Freedman RS, Cowart RE, Cohen DM, Anaissie EJ, Woodside DG, McIntyre BW, Pierson DL, Pellis NR, Rex JH (1998) Multidimensional flow-cytometric analysis of dendritic cells in peripheral blood of normal donors and cancer patients. Cancer Immunol Immunother 45: 234-240.

Sæbøe-Larssen S, Fossberg E, Gaudernack G (2002) mRNAbased electrotransfection of human dendritic cells and induction of cytotoxic $\mathrm{T}$ lymphocyte responses against the telomerase catalytic subunit (hTERT). J Immunol Meth 259: 191-203.

Schuler G, Schuler-Thurner B, Steinman RM (2003) The use of dendritic cells in cancer immunotherapy. Curr Opin Immunol 15: 138-147.

Siena S, Di Nicola M, Bregni M, Mortarini R, Anichini A, Lombardi L, Ravagnani F, Parmiani G, Gianni AM (1995) Massive ex vivo generation of functional dendritic cells from mobilized CD34 ${ }^{+}$blood progenitors for cancer therapy. Exp Hematol 23: 1463-1471.

Strobel I, Berchtold S, Götze A, Schulze U, Schuler G, Steinkasserer A (2000) Human dendritic cells transfected with either RNA or DNA encoding influenza matrix protein M1 differ in their ability to stimulate cytotoxic T lymphocytes. Gene Ther 7: 2028-2035.

Tan PH, Beutelspacher SC, Wang YH, McClure MO, Ritter MA, Lombardi G, George AJT (2005) Immunolipoplexes: an efficient, nonviral alternative for transfection of human dendritic cells with potential for clinical vaccination. Mol Ther 11: 790-800.

Temme A, Morgenroth A, Schmitz M, Weigle B, Rohayem J, Lindemann D, Fussel M, Ehninger G, Rieber EP (2002) Efficient transduction and long-term retroviral expression of the melanoma-associated tumor antigen tyrosinase in $\mathrm{CD}_{3} 4^{+}$cord blood-derived dendritic cells. Gene Ther 9: 1551-1560.

Timmerman JM, Czerwinski DK, Davis TA, Hsu FJ, Benike C, Hao ZM, Taidi B, Rajapaksa R, Caspar CB, Okada CY, van Beckhoven A, Liles TM, Engleman EG, Levy R (2002) Idiotype pulsed dendritic cell vaccination for B-cell lymphoma: clinical and immune responses in 35 patients. Blood 99: 1517-1526.

Uduehi A, Mailhos C, Truman H, Thrasher AJ, Kinnon C, Hart SL (2003) Enhancement of integrin-mediated transfection of haematopoietic cells with a synthetic vector system. Biotechnol Appl Biochem 38: 201-209.

Van Tendeloo VFI, Snoeck H-W, Lardon F, Vanham GLEE, Nijs G, Lenjou M, Hendriks L, Van Broeckhoven C, Moulijn A, Rodrigus I, Verdonk P, Van Bockstaele DR, Berneman ZN (1998) Nonviral transfection of distinct types of human dendritic cells: high-efficiency gene transfer by electroporation into hematopoietic progenitor- but not monocyte-derived dendritic cells. Gene Ther 5: 700-707.

Van Tendeloo VFI, Willems R, Ponsaerts P, Lenjou M, Nijs G, Vanhove M, Muylaert P, Van Cauwelaert P, Van Broeckhoven C, Van Bockstaele DR, Berneman ZN (2000) High-level transgene expression in primary human $\mathrm{T}$ lymphocytes and adult bone marrow $\mathrm{CD} 34^{+}$ cells via electroporation mediated gene delivery. Gene Ther 7: 1431-1437. 
Van Tendeloo VFI, Ponsaerts P, Lardon F, Nijs G, Lenjou M, Van Broeckhoven C, Van Bockstaele DR, Berneman ZN (2001) Highly efficient gene delivery by mRNA electroporation in human hematopoietic cells: superiority to lipofection and passive pulsing of mRNA and to electroporation of plasmid cDNA for tumor antigen loading of dendritic cells. Blood 98: 49-56.

$\mathrm{Wu} \mathrm{MH}$, Smith SL, Danet GH, Lin AM, Williams SF, Liebowitz DN, Dolan ME (2001a) Optimization of culture conditions to enhance transfection of human CD34 ${ }^{+}$ cells by electroporation. Bone Marrow Transplant 27: 1201-1209.
Wu MH, Smith SL, Dolan ME (2001b) High efficiency electroporation of human umbilical cord blood CD $34^{+}$hematopoietic precursor cells. Stem Cells 19: 492-499.

$\mathrm{Wu} \mathrm{MH}$, Liebowitz DN, Smith SL, Williams SF, Dolan ME (2001c) Efficient expression of foreign genes in human $\mathrm{CD} 4^{+}$hematopoietic precursor cells using electroporation. Gene Ther 8: 384-390.

Ying $\mathrm{H}$, Zaks TZ, Wang R-F, Irvine KR, Kammula US, Marincola FM, Leitner WW, Restifo NP (1999) Cancer therapy using self-replicating RNA vaccine. Nat Med 5: 823-827. 